\title{
OPEN Author Correction: A nano- mechanical instability as primary contribution to rolling resistance
}

\section{Jan Meyer ${ }^{1}$, Reinhard Hentschke ${ }^{1}$, Jonathan Hager ${ }^{1}$, Nils W. Hojdis ${ }^{2}$ \& Hossein Ali Karimi- Varzaneh $^{2}$}

Correction to: Scientific Reports https://doi.org/10.1038/s41598-017-11728-6, published online 12 September 2017

This Article contains errors in Reference 17, which was incorrectly given as:

Rodrigues, M. S., Costa, L., Chevrier, J. \& Comin, F. Why do atomic force microscopy force curves still exhibit jump to contact? Applied Physics Letters 101, 203105 (2016).

The correct reference is listed below as reference 1 :

\section{References}

1. Rodrigues, M. S., Costa, L., Chevrier, J. \& Comin, F. Why do atomic force microscopy force curves still exhibit jump to contact? Applied Physics Letters 101, 203105 (2012).

(c) (i) Open Access This article is licensed under a Creative Commons Attribution 4.0 International License, which permits use, sharing, adaptation, distribution and reproduction in any medium or format, as long as you give appropriate credit to the original author(s) and the source, provide a link to the Creative Commons license, and indicate if changes were made. The images or other third party material in this article are included in the article's Creative Commons license, unless indicated otherwise in a credit line to the material. If material is not included in the article's Creative Commons license and your intended use is not permitted by statutory regulation or exceeds the permitted use, you will need to obtain permission directly from the copyright holder. To view a copy of this license, visit http://creativecommons.org/licenses/by/4.0/.

(C) The Author(s) 2019

\footnotetext{
${ }^{1}$ School of Mathematics and Natural Sciences, Bergische Universität, D-42097, Wuppertal, Germany. ${ }^{2}$ Continental Reifen Deutschland GmbH, D-30419, Hannover, Germany. Correspondence and requests for materials should be addressed to J.M. (email: j.meyer@uni-wuppertal.de)
} 